\title{
Documenting the multisensory and ephemeral: Navajo Chantway singers and the troubles of a "science" of ceremonialism
}

\section{Adam Fulton Johnson}

History Department, University of Michigan, Ann Arbor, Michigan

\section{Correspondence}

Adam Fulton Johnson, History Department, University of Michigan, 1029 Tisch Hall, 435 S. State St., Ann Arbor, MI 48109-1003. Email: adamfjohnson@gmail.com

\begin{abstract}
Even as American ethnology in the late-nineteenth century continued to accumulate data about indigenous groups for comparative study, the surgeon-turned-ethnographer Washington Matthews found standardized documentary methods constricting, unable to reflect the complexity of a community's spiritual practices. Through studies of Navajo Indians in the 1880s and 90 s, Matthews experimented with documentation techniques to capture the multisensorial and ephemeral elements of Navajo healing ceremonialism, such as the design of sandpaintings that were later destroyed as the rites concluded. Investigating his ethnographic strategies and his relationships with Navajo knowledge stewards, this article charts Matthews' emerging conviction in social immersion and bonding with indigenous informants, tenets that predated the rise of cultural relativism in anthropology. The article argues that his experience among and tutelage from Navajo medicine "singers" reshaped Matthews' documentary practices to emphasize the irreducibility of cultural facets to tabular columns, raising doubts about then-dominant theories of social evolution.
\end{abstract}

Because he was an Anglo from the east, because he did not know to ask, because he saw no indications of the presence of Navajo gods, it took Washington Matthews 4 years among the Navajo (Diné) to comprehend the multisensory and ephemeral character of Navajo healing ceremonies. Matthews had been studying Navajo language and social forms since 1880 , when he had been transferred to Fort Wingate, in New Mexico Territory, to 
serve as the resident Army surgeon. In his first years as a sometime-ethnographer among the Navajo, Matthews visited their public dances and experimented with writing out the schedule of events during the performances he witnessed. Matthews believed the dances to be part of Navajo religious practice, which had been poorly documented in the literature available to him. But, in 1884, Matthews was shocked to learn that dances were just the tip of the iceberg.

It was only after gaining the trust of some Navajo acquaintances that Matthews was able to see the full extent of the ceremonial practices. Until 1884, he had witnessed only the public portions of extensive Navajo medicine ceremonials, known as "chantways." Chantways were overseen by a "singer," who directed a multiday sequence of events designed to heal certain ailments and oversaw the myriad elements of singing, prayer recitation, fumigation, anointments, and-most striking to Matthews once he finally "discovered" them-the illustration (and ritual dispersal) of elaborate sandpaintings on the ground of the medicine lodge.

The Navajo's sandpaintings captured Matthews' attention; he had not previously seen them, he realized, because they were destroyed as quickly as they were produced. He immediately sought to document these "pictures which are among the most transitory in the history of human art" before they were ritually dispersed into the wind (Matthews, 1885, p. 931). To witness and report the existence of these sandpaintings, and the fleeting chantway ceremony at large, gave Matthews an opportunity to make a novel contribution to the growing archive of American ethnology, which the Navajo had largely eluded for more than half a century. More difficult, however, was the problem of ceremonial documentation: how could Matthews scientifically describe a multi-sensory, ephemeral, and days-long event?

Matthews had inadequate models for such an ethnographic project. As scholars of turn-of-the-century American anthropology have shown, the nascent discipline and its direction through the Smithsonian and its Bureau of Ethnology focused on understanding American Indians as representatives of universal stages of human social development on a linear, step-wise scale, beginning in "savagery" and ascending to "barbarism" and ultimately "civilization" (Bieder, 1986; Hinsley, 1981; Mark, 1980). Ethnologists in the field, used on US Geological Surveys and later through the Bureau of Ethnology, often came from the natural sciences, and their taxonomic skills were readily applied to the comparative study of social groups placed within standardized categories of social "advancement" in areas such as political organization, technology, and linguistic sophistication. To facilitate comparative ethnology, the Smithsonian printed sheets composed of standardized tables, called "schedules," and circulated them to Anglo-Americans located in proximity to Native groups (Fowler, 1975; Johnson, 2018; Turner, 2015). Circulars instructed prospective field agents on how to collect and organize ethnographic information and then return these forms to a central archive in Washington, DC. The problem, for Matthews, was that each new layer of chantway practice he encountered showed him the inadequacy of tabulated categories - the information he collected and analyzed overflowed the ruled and bound pages of schedules. ${ }^{1}$ To document Navajo chantways, and perhaps even glimpse the basis of Navajo thinking, Matthews had to move beyond filling tables.

This article shows how Navajo chantways presented Matthews with a dilemma of documentation: the Navajo's interwoven material, visual, haptic, olfactory, gustatory, and sonic practices escaped the tablebased ethnological categorization and forced Matthews to experiment with new modes of

\footnotetext{
${ }^{1}$ This was literally the case. There is a Bureau of Ethnology schedule book in the Washington Matthews Papers at the Wheelwright Museum Archive, but Matthews did not fill its tables with the sought-after information. Rather, he repurposed the book as a notebook, writing his own notes across the rows and columns. Washington Matthews, Bureau of Ethnology Notebook (circa 1882), in Washington Matthews Papers, Wheelwright Museum Archive, Santa $\mathrm{Fe}$, New Mexico (henceforth WMP). Matthews was not the only Southwesternist frustrated with standardized formats of data accumulations. Frank Hamilton Cushing, who worked among the nearby Zuni Indians, also emphasized the importance of immersive fieldwork and language study; both pioneered this method in 1880s, both highlighted indigenous social complexities over speculation of a group's civilizational "stage." Cushing, like Matthews, forged strong relationships with his informants but focused on a broader view of Zuni life-eventually even "becoming" a Zuni. Cushing's immersive fieldwork-and romantically-tinged ethnographies-have overshadowed Matthews' parallel, albeit comparatively restrained, innovation. While Cushing was among the first ethnographers to "go native" (Green, 1979, 1990) Matthews is an equally important contributor to developing ethnographic fieldwork methods, and he excelled in a particularly underrecognized area: fostering relationships with indigenous informants. For Cushing's contributions to anthropological fieldwork methods, see Hinsley $(1983,1999)$ and Parezo (1985).
} 
capturing ethnographic information. ${ }^{2}$ If Matthews could manage to document a chantway, not only would he reveal the elusive, ephemeral practice of Navajo sandpainting, but the sensorial and symbolic complexity of chantways would chart a prospective route to study the constitutive mental and social structures of Diné life, topics newly in vogue in the adjacent field of American Indian folklore (Bendix, 2009; Zumwalt, 1988). But chantways could not be seen by just anyone. Because the majority of ceremonial processes occurred in private quarters, Matthews needed permission to witness, much less to document, Navajo chantways. Access, in turn, required that he earn the trust of Navajo participants in chantway events. Thus, forging relationships with Navajo willing to vouch for him was crucial to his initial documentary efforts. Later, Matthews would focus predominantly on informants of the highest relevant social standing: the chantway singers themselves. As I show, Navajo singers, assistants, and translators took on pedagogical roles, instructing the Anglo surgeon on the meaning and purpose of ceremonial performance and paraphernalia. Without guidance, it was near impossible for the even the linguistically-able Matthews to understand the icons of the Navajo pantheon that singers and assistants dry-painted on the sandy canvas of the high desert, to grasp the intricacies of ritual paraphernalia construction, or to comprehend the substance of the hieratic language of chant and prayer.

Medicine singers held that a chantway's compositional elements could not be freely shared, replicated, or divorced from their contexts. Navajo chantways were (and remain) composed of sacred, stewarded knowledge bound to Navajoland and subject to principles of coalescence and dispersal (Faris, 1990; Matthews, 1897a; Spencer, 1957). In Navajo chantways, elements of the healing practice were materialized by singers. Then, as the ceremonial ended, these disappeared into the wind. This process of coalescence and dispersal was, for singers, an essential part of the healing process. Disappearance, however, was materially incompatible with ethnographic documentation. Ultimately, Matthews needed to inscribe the ephemeral elements of a chantway on paper, to stabilize parts of the dynamic event and convey these in tandem; to present a chantway as a series of interlocking events would allow it to be understood systematically.

To produce a scientific document, Matthews believed he needed to describe the entire nine-night sequence of a chantway, weaving together the various multisensory and transitory elements that constituted the healing procession. To focus only on the sandpaintings would bring undue attention to a practice that was only one part of the whole. So, in addition to sandpaintings, Matthews endeavored to also document the host of songs and material ritual paraphernalia-when they were deployed, to what end, and when and how they were ultimately quieted or dispersed. His written notes, he hoped, produced a collaged version of chantway processes. Though paper was not a perfect medium for presentation, Matthews attempted to transform the multisensory and ephemeral elements into stable, permanent records. ${ }^{3}$ His subsequent monographs conveyed Navajo ceremonialism with a level of narrative complexity and contingency found only in later ethnographies; through these publications, Matthews offered a model of ethnographic study that presaged historical particularism and the immersive fieldwork methods of anthropology of the early twentieth century.

${ }^{2}$ My use of the term "chantway" follows Spencer (1957). "Chantway" was not a term used by Matthews but one used in Navajo anthropology today. Anthropology has often used the suffix "-way" to capture a range of multisensorial components that make up habitual cultural practices, as in lifeways, foodways, and so on. The use of "-way" may also suggest that habitual practices are not altogether rational, self-aware systems of action but rather unquestioned cultural transmissions from generation to generation. Navajo singers had a clear picture of the transmission of chantway practice, as this paper shows. To complicate matters, Navajo medicine ceremonials have often been translated as songs "toward" some object or goal. Thus, the suffix "way" in the chantway context attempts to capture the directional aspect of the ceremonial, for example, the Mountainway, which might also be called "Chant toward the Mountains."

${ }^{3}$ Matthews' paper documentation was a gesture toward "epistemic virtue," a concept which in the history of science has often meant the suppression of bias or subjectivity to signal a scientists' objectivity. To see Matthews' documentary efforts solely within the framework of objectivity-subjectivity is complicated by the ultimately ineffable nature of his "scientific" object: ceremonialism. A useful alternative framework, especially for sciences investigating "ineffable" experiences and events, has been proposed by Stark and Nancy (2018). Stark and Campbell's "extraction-ingression" framework allows for historical analysis of scientific practices when practitioners used both the tools of (objective) external, materializable data accumulation and (subjective) experiential knowledge-making. Matthews, in his work on ceremonialism, sought to convey objective data to his readers even while recognizing the impossibility of replicable or commensurable experiences at chantway performances. See also, Lemov (2015), Shapin (2012), Cohen-Cole (2014). 
The tutelage of Matthews by Navajo chantway singers shows differing conceptions of knowledge accumulation and use: while Matthews saw social and mental "evolution" in a universal scheme, Navajo singers understood knowledge as deeply situated in time, place, and social memory. Navajo singers conveyed to Matthews that situated knowledge was meaningful and irreducible to any universal form, that chantways were unextractable from their locales and knowledge stewards. Following the work of recent scholars such as Isaiah Wilner $(2013,2016)$ on the role of indigenous informants in shaping anthropological ideas, I show that tutelage from Navajo singers altered Matthews' ethnographic practice, compelling him to appreciate the situated nature of knowledge practices and their cultural relevance. By rejecting standardized, tabulated data accumulation and championing rich, descriptive ethnography, Matthews also unwittingly pushed back on the project of comparative social evolution and laid the groundwork for the rise of contextualized ethnographic studies. ${ }^{4}$ I argue that Matthews practiced in an interstitial period of American anthropology, wherein he paid lip service to social evolutionary ethnology but produced ethnographic work that suggested that a relativistic approach would be necessary to make useable data for an imagined archive of global cultural analysis.

The very idea of making a record of chantway processes was a daunting prospect given the highly structured form of Navajo ceremonialism, its extension over the course of a number of days and nights, and the importance of coalescence and dispersal in the material and aural practices of chantways. Without formal ethnographic training or much in the way of professional (Anglo) guidance, Matthews let his tutors lead the way. ${ }^{5}$ Matthews realized their exalted, learned status allowed them to make decisions about who could and could not know elements of chantways. Through these tutors, Matthews came to understand that ceremonialists drew power and credibility from their mastery of ceremonial scripts, songs and illustrations, all of which called upon the Navajo's Holy People (deities) for aid, blessing, and protection.

Over the course of his decade-long study of Navajo chantways and folklore, Matthews sat and listened, notebook in hand; he wrote extensive notes during his encounters with Navajo chantway singers, translators, and other experienced Native men (few women informants appear in his notebooks). He documented constantly, in cases both sanctioned and unsanctioned, relying mostly on pen-and-paper notetaking. Matthews used a number of different writing strategies to document chantway processes. During his viewings of two chantways, the Mountainway and the Nightway, he scribbled quick entries, time-stamped when he could glance at his watch in the midst of an event:

6.30 [PM] corral, 8.20 orchestra, 8.30 torch applied, 8.40 wand dance, 8.50 ends, 9.15 great arrow (poorly done), 9.32 whistle, 9.34 enter 8 men and a leader (some naked)... 10.15 dance of Manuelito's $5 \mathrm{yr}$ old boy to the living feather in the basket. ${ }^{6}$

Only quick notation could trace the fleeting nature of songs, dances, sandpaintings, and ritual blessings of a chantway. In addition to scribbling the "live" sequence of events in situ, Matthews interviewed ceremonialists in private, clandestinely observed healers and their patients, transcribed songs recorded on wax cylinders, and, when his notetaking was barred, made notes and sketches from memory immediately following chantway events.

Matthews' inscription work can be seen as a form of "redimensionalization"-flattening time and space into transportable marks on paper. Following the work of Hans-Jörg Rheinberger, the process of redimensionalization describes the transformation of an event (or experiment) in time and space onto a two-dimensional surface. In Rheinberger's conception, the "reduction to a surface facilitates exploration of new ways of ordering and arranging

\footnotetext{
${ }^{4}$ In the popular genealogy of American anthropology, the break with social evolutionism is regularly attributed to the figure of Franz Boas, although scholars such Regna Darnell $(1998,2001)$ have questioned an emergent "Boasian revolution" of historical particularism.

${ }^{5}$ Matthews was a pupil of several medicine men, namely Laughing Singer and Tall Chanter, who are discussed below. Matthews maintained a strong relationship with a translator named Jake the Silversmith, also called Biolzog (Silversmith) and Náltsos Nigéhani (Paper Carrier), who performed some shorter chantways and assisted with many others. He also forged lasting relationships with other prominent medicine men. Matthews' notebooks mention Old Torlino and his son, Torlino; Gordo; Nosey; Manuelito; and the translators Jésus Arviso, Ben Damon, and Chee Dodge.

${ }^{6}$ Washington Matthews, Ceremony and Weaving Notes (1884), WMP.
} 
data: sequential events can be presented in synchronic form, temporal relations as spatial" (Rheinberger, 2010). To represent Navajo chantways, Matthews needed to condense long and complex events into a two-dimensional written form; once done, patterns could be identified at various levels of condensation. Matthews' redimensionalization of the elements of chantways mapped out a documentary strategy for making multisensory and ephemeral practices into permanent paper records.

When Matthews eventually published his lengthy studies of the Navajo Mountainway and Nightway, his hybrid form of ethnographic documentation established a textual model of documenting ceremonial complexity, one used by later ethnographers of the Navajo such as Alfred Tozzer and Berard Haile. The complexity of his ceremonial documentation revealed, however, that a comparative science of ceremony could only begin with the establishment of thorough, specialist texts on individual indigenous ceremonial practices. Specialist texts, moreover, required unbiased observers who respected-or at least appeared to respect-the indigenous knowledge traditions of their interlocutors, for only then would ethnographers be welcomed to the most intimate and sacred practices of their host community. Though he was inspired by the work of the Bureau of Ethnology and its dedication to a global human science, the research imperatives Matthews found most suitable for ceremonial study cast ceremonialism as radically situated in place and time. In the end, Matthews' advancement of the study of ceremonialism illuminated the incommensurability of comparative ethnological data, a premonition of the rise of the disciplinary norms of participant observation and thick description.

\section{1 | LEARNING OF NAVAJO CHANTWAYS}

Washington Matthews was posted to Fort Wingate as a medical officer in 1880, coming to New Mexico with the additional support of the Bureau of Ethnology to pursue ethnological work among the Navajo as a side project to his role as the fort's surgeon. ${ }^{7}$ Given that the Army surgeon had previously composed a philological study of the Hidatsa (Matthews, 1877), the Bureau of Ethnology's director, John Wesley Powell, trusted that Matthews could correct or improve upon previous reports of the Navajo. Just as Powell envisioned, Matthews immediately began to accumulate a vocabulary and learn the Navajo language, as well as engage in studies of Navajo industries of silversmithing (Matthews, 1883) and weaving (Matthews, 1884).

Unlike the neighboring Pueblo Indians, who had been better documented, the Navajo were poorly understood in 1880, regularly portrayed as regional troublemakers and anarchic wanderers, without government or religion (Simpson \& McNitt, 1964). Jonathan Letterman, a former Army doctor at Fort Wingate, had reported in 1856 that he had found no evidence of a systematic religion among the Navajo. "It is impossible to learn anything from the people themselves, as they have no traditions," Letterman wrote. "A volume of no mean size might be written, were all the stories of interpreters taken for truth; but it would be found one mass of contradictions, and of no value whatever" (Letterman, 1856). Letterman had foreclosed the possibility of an ethnography of Navajo religion because he did not find (or chose to deem inauthentic) evidence of consistent spiritual practices. Yet, after 4 years among the Navajo, Matthews had learned of the social role of medicine practitioners, called hataatii or "singers," and suspected that Navajo spiritual practices ran deeper than Letterman had presumed. His hunch led him, ultimately, to "discover" the Navajo practice of sandpainting in 1884.

\footnotetext{
${ }^{7}$ Halpern and McGreevy's (1997) edited volume provides a broad assessment of Matthews' contributions to Navajo studies, including to topics such as ceremonialism (Frisbie, 1997), drypainting (Parezo, 1997), folklore (Halpern, 1997), and fieldwork ethics (Faris, 1997). His intellectual contributions to anthropology were explored in Poor (1975), primarily through an analysis of his published materials. Paul Zolbrod (1981, 1997, 1998) has made excellent use of Matthews' song and story transcriptions for translation and literary studies of Navajo oral culture, as has Anthony Webster (2004, 2009). Nancy Parezo (1983, 2006), James Faris (1990), and Paul Zolbrod (1998) have all, respectively, noted the difficulty of ceremonial documentation. My work is indebted to these prior scholars, although my aim is not to recuperate or repurpose Matthew's ethnographic material but to explore the tensions between the practices (and embedded assumptions) of scientific documentation and the multisensory, ephemeral (and ultimately ineffable) character of Navajo chantways.
} 
In October of 1884, Jake the Silversmith, who had previously helped Matthews in his Navajo industry studies, led Matthews to Niho'tlizi (Hard Earth), a camp seated in the pine forest foothills near the San Mateo mountains of western New Mexico. Matthews pitched his tent on the outskirts of these encampments, a bit away from the brushand-earth medicine lodge and sleeping corrals that doubled as preparation areas for the medicine ceremonial. Jake vouched for Matthews, and the presiding chantway medicine singer allowed the Anglo to witness the ceremonial events in the medicine hoogan.

Medicine singers came to camps such as Niho'tlizi in the late fall and winter, when the bears and snakes were sleeping away the cold. The camps served as gathering places for psychically or physically afflicted Navajos. Here, stories could be told and patients could receive a healing through a sing. ${ }^{8}$ Chantways were primarily ceremonials for the curing of a disease, and secondarily provided blessings for friends and family. A singer would be found and paid the appropriate fee-a suite of horses or other beasts of burden, ceremonial supplies such as eagle feathers or rare sorts of wood, food and water, perhaps some American dollars-and then the preparations for a sing would begin. ${ }^{9}$ While portions of the ceremony had a serious air, over the many days it took to complete the ceremonial cycle a small community would cohere and commiserate, share stories and gossip, eat well, and recount histories of the people from the earliest times (Matthews, 1887).

Jake had brought Matthews to a specific chantway called the Mountainway, which was to be "sung over" a female patient with an unrecorded affliction. ${ }^{10}$ With the help of Jake and Chee Dodge, a Navajo trader fluent in English, Matthews attempted to capture his experience of the Mountainway on paper. ${ }^{11}$ Matthews looked on as the singer proceeded to make ceremonial objects and anoint the one-sung-over (the patient) with various herbs. Across 4 days, Matthews witnessed four elaborate sandpaintings executed-"large and beautiful sketches in 5 different colors drawn on the sanded floor of the medicine lodge to represent different cosmogonic and religious conceptions." ${ }^{12}$ The one-sung-over was then directed by the singer to sit atop the sandpainting. Healing continued through singing and anointment with prayerstick bundles. ${ }^{13}$ At the end of the procession of songs, the patient retired from the hoogan to lodges erected by friends and family. Meanwhile, the singer erased the sandpainting and removed the sand to a discreet place beyond the camp.

Sandpaintings were extracted and dispersed because they had been rendered tainted through the ceremonial, the disease transferred from the patient to the sand-depictions of the Holy People (Matthews, 1887). ${ }^{14}$ But Matthews had been able to illustrate the sandpainting before the singer and his assistants destroyed it and removed all trace of the sand. He wrote to Powell:

I obtained accurate watercolor paintings of these sacred pictures and accurate description of the process of forming them (and this is a material and significant fact). Soon after each picture was finished it was with interestingly significant and consistent ceremonies erased, and the very sand on which it was drawn removed from the lodge. ${ }^{15}$

\footnotetext{
${ }^{8}$ Washington Matthews, Bureau of Ethnology Notebook (circa 1880-84), WMP.

'Washington Matthews, "Conditions near Manuelito," Journal, 16 October 1887, WMP.

${ }^{10}$ Significantly, the tools of Navajo medicine in chantways such as the Mountainway were not directed at the manifestation of disease, but rather pointed toward the factor causing it.

${ }^{11}$ Washington Matthews, "San Mateo and Hackan" (1884), WMP. Matthews noted the ceremonial's singer as Tsi-toa'ci, about whom almost nothing is known.

${ }^{12}$ Washington Matthews, "Original Draft of Monthly Report to Major Powell" (1884), WMP.

${ }^{13}$ On the Mountainway, see Wyman (1975), Faris (1990).

${ }^{14}$ Nancy Parezo (1983) phrases this nicely: "Dramatic and ephemeral, beautiful in that it attracts holiness actively, a drypainting exists in time and space only for the duration of a ceremony; when its use is fulfilled, it is ritually erased."

${ }^{15}$ Matthews, "Original Draft of Monthly Report to Major Powell," WMP.
} 
Matthews was struck by the novelty-and, it follows, the ethnological value-of his experience; to his knowledge, no white man had ever written about Navajo sandpainting or the myriad songs and sacred materials of the Navajo's "religion." A whole range of research possibilities, a hidden treasure of ethnographic data, had been revealed to Matthews.

Although the surgeon was clearly captivated by his ethnographic project, his continued fieldwork was slowed by his employment as an Army surgeon. Matthews was in the midst of a transfer out of the field, to the Army Medical Museum and Library in Washington, DC. After seeing a Mountainway with Jake, he inquired with other medicine singers about the complicated rites he had witnessed. "I opened negotiations with three different medicine men, offering them as liberal terms for their services as I could afford, but only to meet with the most positive refusal," Matthews reported to Powell. ${ }^{16}$ Many singers were reluctant to share knowledge with an outsider, a white man associated with the Anglo forts designated to monitor the Navajo people. But near the end of his time in Navajoland, Matthews "heard of an old shaman living beyond Nutria about 70 miles distant, who it was thought would be found less scrupulous than the others had proved. (Matthews, 1887)." This well-known singer, Tall Chanter, arrived at Fort Defiance in eastern Arizona just before Matthews' departure. "With some trouble I concluded a bargain with him and he began his narration," Matthews recounted. "No doubt I could profitably spend several months with him did circumstances permit." ${ }^{17}$ His limited time with Tall Chanter notwithstanding, Matthews had already decided to move forward with a robust study of the Mountainway. ${ }^{18}$ Even during his post in the American capital, he reasoned, he might still pursue a study of Navajo ceremonialism. If he could not witness a chantway in Navajoland, he could nevertheless bring a Navajo singer to Washington. So, he asked Tall Chanter to journey east.

\section{I TALL CHANTER AND TEACHING CHANTWAY FUNDAMENTALS}

The renowned Diné medicine singer Tall Chanter (Hatali Nez, c. 1841-1929) travelled from his home in Rainbow Springs, in the southeastern portion of Navajoland, to Washington in November of 1885. Tall Chanter had been trained as a hataatii by his father, Mr. Cane, before the events of the Navajo's Long Walk, the infamous forced relocation of Navajos from Navajoland to Fort Sumner between 1864 and 1868 (Faris, 1990). The trip was secured through an arrangement with the Navajo Agent Dennis Riordan and Bureau of Ethnology director Powell, and included an introduction to the American President, Grover Cleveland. Tall Chanter and his Navajo entourage spent time in Washington meeting various scientific and governmental personnel, with Chee Dodge acting as interpreter. While there, Tall Chanter also found time to work with Washington Matthews at his post at the Army Medical Museum.

Tall Chanter required Matthews' trust and goodwill in order for training to occur, and Matthews endeavored to honor his "elder brother."

Before he would confide any of his secrets to the author he said: "The chanters among the Navahoes are all brothers. If you would learn our secrets you must be one of us. You must forever be a brother to me. Do you promise this?" He has ever since addressed the author as Sitsi'li, "My younger brother," and has in turn been called Sinái, "My elder brother" (Matthews, 1901).

Singers formed a sort of fraternity of practitioners, bound by their shared expert knowledge of Navajo cosmology. Singers took the healing role seriously, and they built their reputations through the patients and

\footnotetext{
${ }^{16}$ Matthews, "Original Draft of Monthly Report to Major Powell," WMP.

${ }^{17}$ Matthews, "Original Draft of Monthly Report to Major Powell," WMP.

${ }^{18}$ Though drawn away from the field, Matthews first communicated his findings on Navajo ceremonialism in 1885 in the American Naturalist, where he emphasized the presence of sandpaintings, which he called "dry paintings" (Matthews, 1885). An abstract of this paper was also published in the Bulletin of the Philosophical Society of Washington 8 (1885). Matthews was annoyed to find that another Bureau of Ethnology employee, James Stevenson, witnessed a Nightway later in 1885 and managed to publish his account before Matthews.
} 
communities they served. Across the scattered range of Navajo bands, singers could become cohesive practitioners, linking family groups across diverse terrain.

The chantways performed by singers like Tall Chanter were ceremonials designed to maintain hózhó, harmony and balance, of people and environments. ${ }^{19}$ Navajo medicine, like all systems of healing, treatment, and etiology, composed a body of knowledge directed at states of health and wellbeing of the human body. Much like Anglo medicine, too, this corpus of knowledge was distributed among different specialists, and ailing Navajo went to a number of practitioners based on the condition that troubled them. Herbalists, diagnosticians, prayer-makers, and chantway singers were termed nahałaii ("practitioners"), indicating skill and knowledge in matters of healing. ${ }^{20}$ Medicine singers such as Tall Chanter and Matthews' later tutor, Laughing Singer (Hatali Natloi), had undergone additional training, and received the honorific title given to learned singers, hataatii, who had mastered at least one entire chantway. ${ }^{21}$ Hataatii administered two, five, and nine-night chantways, and they were necessarily skilled in a paradigm of medicine focused on blessing and dispelling, returning patients to a state of happy equilibrium, to hózhó. ${ }^{22}$

Tall Chanter had spent years mastering chantways, but he could not recreate a chantway in Washington because the Holy People, the Navajo deities called forth through songs and sandpaintings and compelled to use their powers to restore balance, did not dwell in this land. The Navajo theory of healing associated particular afflictions with particular Holy People, who lived only within the domain of Navajoland (Wyman, 1975, p. 5). In lieu of a full presentation of a chantway and its sandpainting designs, it appears Tall Chanter instead instructed Matthews on the materials and histories that undergirded them. ${ }^{23}$ According to Navajo thought, Holy People unfurled the designs for sandpaintings on the clouds and taught them to various storied heroes and heroines, who had passed them down through generations of hataatii. Contemporary singers used the designs, prayers and songs to call forth the Holy People. Tall Chanter provided Matthews a groundwork for understanding Navajo chantways, even if the singer would not enact one away from Navajoland. ${ }^{24}$ This proved to be a fundamental introduction for Matthews, one that imparted to him the importance of strong relationships with the stewards of ceremonial knowledge for sustained ethnographic study. With an additional base of knowledge in the Navajo pantheon and ceremonial philosophy, Matthews needed to return to the place where the Holy People resided, where singers actually performed the chantways.

\section{3 | "THE MOUNTAIN CHANT: A NAVAJO CEREMONY" (1887)}

When Matthews eventually returned to New Mexico in autumn of 1887 to witness another Mountainway under the singer Gordo, Tall Chanter was there to meet him in the singer's camp. During his second chantway viewing, Matthews documented the construction of the medicine lodge and the purgative rites featured in the first days of

\footnotetext{
${ }^{19}$ For discussions of the complex concept of hózhọ, which I cannot adequately relate here, see Kluckhohn (1949), Reichard (1950), Witherspoon (1977), Farella (1990).

${ }^{20}$ Schwarz (2003). Witchcraft was defined by Kluckhohn (1944) as "the influencing of events by supernatural techniques that are socially disapproved." Witches were also present within the complex of Navajo "medicine," although these were considered not healers but disruptors of harmony (hózhó).

${ }^{21}$ I have kept Matthews' spelling for his singers' names as "Hatali." "Hataatii" is generally preferred by Navajo today.

${ }^{22}$ Anthropologists have long sought to understand the Navajo ceremonial system through organization of the elements in formal, philosophical terms. Aside from Matthews' pioneering work, Wyman and Kluckhohn (1938) developed a Navajo "ceremonial classification" based upon the apparent importance of the ceremonials. Haile (1938) divided ceremonials by the presence or absence of a rattle, which distinguished a chant (with rattle) from a rite (without). Subsequent authors built upon these classifications. Kluckhohn (1949) later investigated the notion of hózhó, harmony and balance, and the role of "religion" in maintaining these elements. Gladys Reichard (1950) examined the philosophical underpinnings of Navajo life, in part through chantways and rites of Navajo "religion." Spencer (1957) organized chantways according to mythological content. Wyman's (1970) later work analyzed individual chantways and, like Reichard and Kluckhohn, worked toward a categorization scheme for the interfacing components of Navajo religion.

${ }^{23}$ See Matthews, "Flora/Fauna Terms" (1885), WMP; Matthews (1902).

${ }^{24}$ Even if he had not been formally trained as a Mountainway singer, Tall Chanter would have been considered a knowledgeable onlooker, one who knew the cosmology the singer referenced and could critique or commend as needed. See Faris (1990).
} 
the ceremonial and made many sketches of sandpainting designs and ceremonial objects as the nine-night event proceeded. While the singer Gordo appeared to welcome Matthews, he did not offer the Anglo visitor commentary on the Mountainway performance. Instead, Matthews drew on Tall Chanter and the translator Chee Dodge, both of whom helped the ethnographer better understand the events before his eyes.

His trip in 1887 was short but productive. Matthews took his notes and experiences and, back in Washington, transformed them into a scholarly text. Unlike his first viewing, Matthews had the help of willing Navajo ceremonialists to interpret his experience of the Mountainway, guidance that allowed him to supplement his in-situ notes with commentary and folklore. The event became a text-a transformation of the nine-night procession of songs, prayers, dances, sandpaintings, anointments, fumigation, and a host of other sensorial events, into an illustrated, 88-page text, entitled "The Mountain Chant: A Navajo Ceremony."25

"The Mountain Chant" implicitly pursued complicated ethnographic questions: how to represent a ninenight ceremonial event that overwhelmed the senses? How to document ceremonial elements that were destroyed and dispersed as part of the process of healing? Matthews' 88-page ethnography began with a long mythological account of the Holy People's gift of the Mountainway. Only after some 30 pages did Matthews begin to describe the actual events of the Mountainway. ${ }^{26}$ His description of the events focused on reproducing the nine-night temporal sequence entirely, without deviation into specifics. Sandpainting preparations, for instance, were described in the course of the chantway sequence. But the details Matthews "deferred until all might be drawn together," placing a thorough description and symbolic analysis of the four sandpaintings associated with the ceremonial in a third section of the work (Matthews, 1887, p. 422). Song transcriptions, too, he placed in a fourth section, wherein songs were written in Navajo, followed by a literal English translation and another, more poetically rendered free translation. Each song was followed by a short explanation of the song's meaning or role in constituting the chantway. To orchestrate the myriad features, Matthews' had decided to make his representation of the chantway synthetic, a blend of his two viewings of the Mountainway in addition to information provided by Tall Chanter, Chee Dodge, and Jake the Silversmith, and other unnamed informants.

The entire work was ordered by numbered paragraphs (and a detailed table of contents), which facilitated the reader's orientation in the text and enabled references to be made to prior or forthcoming sections. For example, the first sandpainting, "The Home of Bear and Snakes," appeared in the main text in paragraph 93, and the reader was at this point alerted that a description would come later, at paragraph 160 . Upon reaching paragraph 160 , the reader could also reference the mythological account (paragraph 53) that the painting evoked. Songs, too, were indexed throughout the sequential text and in the later section featuring songs in Navajo and English translation. ${ }^{27}$ The indexical strategy provided a means to represent the chantway dynamically, an attempt give synchronous texture to an otherwise dialogical textual structure.

"The Mountain Chant" was the first in-depth study of a single Indian group's "religious" rites in the Bureau of Ethnology's Annual Report. Similar in its sustained focus to work by a colleague, Frank Hamilton Cushing on Zuni (Puebloan) ritual carving and pottery (Cushing, 1883, 1886), Matthews' publication distinguished him from his contemporaries through its systematic redimensionalization of Navajo ceremonial life-or one possible iteration of it. Matthews had presented a model for a concentrated and particularistic mode of ethnographic study: the complexities of indigenous ceremonial systems could be organized and described in logical and signposted forms, and links between different components (as in the sequence and the sandpainting and the myth), established in indices and cross-references, could be drawn together to approximate the totality of the

\footnotetext{
${ }^{25}$ Matthews (1887). While the volume identifies its publication date as 1887 , it was not actually published until 1888 , which accounts for Matthews' ability to include information collected in Fall of 1887 in the article.

${ }^{26}$ The rendering of "dsilyídje qaçàl” is from Matthews' orthographic scheme. For the idiosyncrasies of Matthews' Navajo orthography, its changes over time, and its retooling for contemporary linguistics, see Halpern and McGreevy (1997).

${ }^{27}$ Matthews (1887). For a discussion of the various components of the Mountainway and developments since Matthews' time, see Wyman (1975).
} 
event. $^{28}$ In all, "The Mountain Chant" was a novel form of ethnographic documentation in American anthropology. The monograph's extensive detail and use of cross-references set a high standard for an integrated, dynamic description of ceremonial processes, their epidemiological and etiological theories, and their underlying constitutive meanings. The monograph provided Matthews with a model for continuing exploration of the problem of capturing multisensorial and ephemeral events, but the very complexity of the documentary project also indicated the troubles of comparative ethnological data collection. Yet, given his later inquiry into a "science" of ceremonialism (Matthews, 1897b), Matthews likely maintained hope that "The Mountain Chant" could be useful to comparative ethnology, a dense text from which information might be distilled into distinct data categories of "universal" ceremonial elements.

\section{4 | THE PROBLEMS OF CHANTWAY DOCUMENTATION VERSUS CHANTWAY UNDERSTANDING}

"The Mountain Chant" demonstrated a method for redimensionalizing an event of sensorial complexity that occurred over multiple days. Qualitative, exhaustive documentary methods were rare in ethnology; formalized training in ethnographic anthropology would only begin in the 1890s (Mark, 1980). American ethnology had been directed by the Smithsonian and Bureau of Ethnology through paper circulars, which detailed and categorized ethnographic areas of study on table-based schedules. Schedules were self-contained paper technologies of data accumulation that provided both scholarly guidance and a medium for inscription; field agents filled in tables on the preprinted forms and then returned them to a central repository in the Bureau of Ethnology (Johnson, 2018; Turner, 2015). While Matthews had received a Bureau of Ethnology book of schedules sometime before 1882, he did not use it to its intended end, instead repurposing the volume as a notebook for his own use. ${ }^{29}$ Other emerging documentary technologies promised novel ethnographic perspectives, but these nascent media were difficult to reproduce and circulate. Wax cylinder recordings and photographic cameras-both of which Matthews occasionally used-could only supplement ethnographic studies of ceremonialism that required attention across the sensorial spectrum. In 1887, Matthews' printed rendition of a Navajo Mountainway was the most advanced and exhaustive technology for conveying complex information on indigenous ceremonialism to a wide audience.

Matthews returned to Navajoland in 1890, retaining his position as Army surgeon at Fort Wingate and continuing his study of Navajo chantway ceremonialism through 1894. Building on the textual model he constructed for the Mountainway in 1887, Matthews turned to study of another important chantway, the Nightway, linking his work to questions of American Indian "mentality" percolating in the field of folklore studies. In addition to Tall Chanter, Matthews enlisted the aid of another well-regarded chantway practitioner, Laughing Singer. ${ }^{30}$

Over the winter of 1891-92, Laughing Singer (Hatali Natloi, c. 1833-1923) instructed Matthews on the methods of making ceremonial paraphernalia, materials that singers and assistants would produce in the lead-up to a Nightway, and which (like sandpaintings) would be disassembled, distributed, or otherwise transformed during the course of the ceremonial. ${ }^{31}$ Chantway paraphernalia were composed of a host of objects, and attention needed to be paid to the circumstances of their collection and the orientation of the composition as an

\footnotetext{
${ }^{28}$ Part of "The Mountain Chant" was suppressed by the Bureau of Ethnology, a portion which contained a description of the sexualized public performances that came in the final evening of the event. After protests from scholars, many lamenting the patronizing censorship of the Bureau and government science in general, a supplement, "The Suppressed Part of the Mountain Chant," was published in 1892.

${ }^{29}$ Matthews, Bureau of Ethnology Notebook (circa 1882), WMP.

${ }^{30}$ Laughing Singer, known across Navajoland as a jovial and generous singer, had trained under the tutelage of No Sense Old Man before the forced relocation of the Navajo in the Long Walk to Bosque Redondo in 1864 (Faris, 1990). When he returned from Bosque Redondo in 1868, he eventually made seasonal homes near Cottonwood Springs and Dilkon, abutting the Hopi Mesas.

${ }^{31}$ Laughing Singer demonstrated the production of multiple ceremonial objects such as a turquoise bead noise-maker; a buffalo horn filled with tallow of different mountain animals; an eagle-bone whistle; and a variety of prayer-stick offerings of twig, feathers, and other materials bound with string. Washington Matthews, "Ceremonial Tech and Notes" (circa 1891-92), WMP.
} 
object was made to entice the Holy People to provide healing. In these tutoring sessions with Laughing Singer, Matthews came to appreciate the importance of memorization in the training of chantway practitioners. Ceremonial objects, like sandpaintings and songs, were not written down; trainees practiced in sections, dividing up elements into discrete practice sessions. ${ }^{32}$ There were many songs to learn, stories to master, paintings to perfect, and recipes to be remembered.

Writing notes became crucial to Matthews' studies with Laughing Singer. Watching his tutor work, Matthews listed ingredients and drew sketches of item construction in his notebook, likely the first time such important Navajo knowledge and practices had been inscribed into permanent, paper form. During his field tutelage, the surgeon kept separate notebooks for song transcriptions, "ceremonial tech," flora and fauna terms, weaving notes, and dictionaries and phrasebooks. Matthews' notebooks showed his application of Anglo learning techniques-the use of paper records to capture lessons. His notes also showed an emerging dynamic between the tutor and tutored: even while his teachers understood Matthews would not actually practice chantway healing, Tall Chanter and Laughing Singer sanctioned his documentation of chantway elements, indicating their willingness to make permanent records of experiential training practices. Their apparent openness was not necessarily shared by other respected Navajo singers. But what protected these practices from desecration, for Tall Chanter and Laughing Singer, was that chantways could not be replicated outside of Navajoland (as Tall Chanter had informed Matthews during the former's visit to Washington, where the Holy People did not dwell), nor could they be practiced without elder singers shaping the training itself. Tall Chanter and Laughing Singer may have also appreciated Matthews respectful, active interest in their healing practices, too, considering that their student was a healer in the Anglo tradition.

Only through his relationships with Tall Chanter, Laughing Singer, and other knowledge stewards was Matthews able to understand the ways in which chantways reflected Navajo cosmology, and how histories and myths constituted the healing powers of chantway practice. Strong relationships were part and parcel of chantway practice, and Matthews' informants often emphasized this point. ${ }^{33}$ Navajo singers conveyed they were not "gifted" or special individuals with an inborn or hereditary power; hataatii needed to pass on their mastery, for it was only through apprenticeship that new medicine singers could become adept in the suite of practices that composed chantways. ${ }^{34}$ Nearly all of the information he scribbled into his notebooks needed to be conveyed to him through dialog or handson training with a singer; little could be passively witnessed or interpreted without a knowledgeable guide.

During one training session, Matthews had trouble fully understanding an intricate explanation of the required properties of a yucca-leaf drumstick. Ben Damon, who often aided Matthews with translation, could not translate Laughing Singer's words into English. Laughing Singer offered to show Matthews how to construct a drumstick from yucca leaves, telling him "anybody may make the drumstick." Matthews recounted in his notebook the attention to detail and perfectionist sensibilities Laughing Singer (here, Natloi) brought to their search:

I go out to find yucca for drum sticks with Ben and Natloi in P.M. We hunt an hour and pass a hundred yuccas before we find the right one. Then he isn't quite satisfied, the leaves must be large tall straight, green, introverted. The four good leaves must be found on it. The fringes \& tops of all are taken off and put into heart of plant, leaves must be pulled out not broken off. Must be made in house-peculiar way of making. How shall I describe, east \& west put back to back, tied together, lateral binding strings put in, two strands tied round, binding-strings passed through, 5 lines once for each night. ${ }^{35}$

Though difficult to render into written form ("how shall I describe..."), Matthews attempted to capture the intricate metaphysics of orientation in chantway preparation. He knew that cardinal directions had particularly

\footnotetext{
${ }^{32}$ Matthews (1902). If a sandpainting did not contain the full image, the appeal to the Holy People was not communicated.

${ }^{33}$ Matthews, "San Mateo and Hackan," WMP; "Jake Windway Notebook" (ND), WMP.

${ }^{34}$ For a discussion of training lineages, see Faris (1990, pp. 82-83, 235).

${ }^{35}$ Matthews, "Ceremonial Tech and Notes" (circa 1891-92), WMP.
} 
meanings for Navajos, especially the East, the direction from which goodness came. But in learning how to make prayersticks and drumsticks, he also came to appreciate the deliberate ways that singers oriented materials toward certain directions, toward important historical and spiritual sites in Navajoland. Drumstick creation, he realized, required attention to one's situatedness in space within the bounds of Navajoland.

Like many ceremonial elements, the yucca-leaf drumstick would normally be disassembled after use in a ceremony. However, because Matthews constructed one outside of a chantway event and under Laughing Singer's guidance, he was allowed to keep the drumstick. Indeed, it may have served him as a reminder of the necessity of experiential training and comprehension of the Navajo's theory of situated healing. During an evening lecture presentation on the drumstick and its partner, the basket drum, Matthews explained:

I have had several drumsticks made and pulled apart for my instruction, and I have made them myself, under the observation and criticism of the shaman [singer]. This one I was allowed to retain intact. No one has ever sung or prayed over it. It has never been used in the rites. It was therefore unnecessary to tear apart, to release its soul and sacrifice its substance to the gods (Matthews, 1894).

Here, Matthews interpreted Laughing Singer's permission as a rule of Navajo knowledge: when not tied to Holy People (and thus to potential misfortune from offense), knowledge could remain stabilized in its material form, separated from the mind of the singer-a belief that appeared to extend to Matthews' own notetaking practices. As such, Matthews believed he could convey this information to Anglo audiences-a paradoxical task, given that Matthews himself had learned by doing. Indeed, just like Laughing Singer, Matthews could not describe how to make the yucca-leaf drumstick, he could only demonstrate its construction. Unfortunately for his audience, he had no fresh yucca on hand:

[S]ince the shaman cannot adequately explain in words, to the devotees who assist him, how the stick is made I shall not attempt the task for you tonight. I have learned how to make it; but I have, now, no fresh yucca leaves on hand to illustrate the process of making. So I shall say nothing more of the process. Anyone who is not satisfied with this decision may come with me to the yucca-covered deserts of Arizona and there I may show him how to make a drum-stick (Matthews, 1898).

Here, in addition to posturing about his singular experience, Matthews emphasized Tall Chanter's lesson that chantways could not be performed outside of Navajoland; he recognized that the transfer of some ceremonial knowledge was necessarily experiential and context-dependent. This was an implicit recognition of Navajo forms of training-a pupil should learn from direct study and practice under knowledge-keepers. Yet, by training Matthews and recognizing his documentary motive, Laughing Singer and Tall Chanter suggested they were open to expanding the modes of knowledge communication. Writing and drawing might supplement teaching, aid comprehension in singers-in-training, or even expand the number of apprentices in training without diminishing the chantway's healing abilities.

By attending to the minutia of orientation and sequence in the creation of the drumstick, Matthews demonstrated his commitment to ceremonial study as a trainee, as someone invested in this Navajo knowledge system. His accumulated ceremonial training could thus be rendered into written form, as ethnographic knowledge about Navajo beliefs. He did eventually distill the drumstick lesson into an article on the Navajo philosophy of orientation and sequence. Matthews' (1892) article, "A Study in Butts and Tips," detailed the "tediously numerous and minute" ceremonial observances of Navajo singers, especially regarding the orientation of objects in space relative to the cardinal directions. In this study, he asserted the moral imperative of patience that the scientist must endeavor: "The study of symbols in any one race of people, in any one order of priesthood or in any one ceremony may be fruitless; but let us record painstakingly what we observe, and in the course of time the comparative study of our observations may bring a solution" (Matthews, 1892, p. 345). As he often did, Matthews framed his work as a contribution to a larger comparative ethnological project, and himself as a humble fieldworker, dedicated to 
accumulating exhaustive information about a specific form of ceremonialism. But the article alluded to the difficulty of understanding the internal logic of orientation practices: it was one thing to write out a detached description of the construction of a ritual object; it was another endeavor to spend the time-and build the relationshipsnecessary to comprehend the underlying theory of its construction.

The articles Matthews produced during the second phase of his study of Navajo chantways are characterized by a tension between the description of discrete elements that came into play during a chantway and the requirements for an ethnographer to believably comprehend a ceremonial process-a problem of two levels: access to sacred events and then capturing multisensory and ephemeral processes in situ. Among all of the difficulties of multisensory and ephemeral data capture, Navajo chantway songs and prayers presented a distinct problem of documentation; each night of a chantway contained dozens, even hundreds of individual songs and prayers. Moreover, many songs and prayers featured elements that were composed in a hieratic mode, meaning they were of an ancient idiom, no longer in everyday use. The song patterns themselves carried power that allowed the chantway to proceed, usually connected to a myth that preceded and constituted the song. Singers could not simply improvise: "A score or more of critics who know the song by heart are listening with strained attention. If the slightest error is made it is at once proclaimed, the fruitless ceremony terminates abruptly, and the disappointed multitude disperses" (Matthews, 1896, p. 198). Song mastery was a daunting task for chantway students; hataatii were expected by their peers to perfectly know the hundreds of songs that might accompany a chantway.

Once again, Matthews used Anglo technologies of documentation in lieu of pattern memorization. With the aid of wax cylinders, Matthews made audio recordings of chantway songs and prayers, as well as a host of other Navajo songs. To aid his interpretive efforts, Matthews regularly made notes about associated meanings or histories learned from his tutors in Navajoland, which he placed on the verso page, facing the recto page's song transcription. ${ }^{36}$ Laughing Singer became Matthews' most reliable performer for these recording sessions, as evidenced by his frequent attribution in Matthews' notebooks on his cylinder recordings. With such recordings, which occurred outside the ceremonial setting, Matthews was able to spend time transcribing songs after Laughing Singer had retired, analyzing the sonic patterns and sequences. But even though cylinder records made Navajo songs mobile and stable, without a knowledgeable steward to guide the process the audio record would be useless as data. Laughing Singer not only indulged in song performance and demonstrated mastery, he also provided commentaries on many of the songs he sung, iteratively teaching the pantheon and Navajo history to his ethnographer-student. ${ }^{37}$

As his tutelage under singers continued, Matthews appeared to recognize the divide between ethnographic observation and epistemological comprehension in his writing. Redimensionalization of drumstick preparations or song sequences would confirm the existence of such practices for the ethnological record, but more contextualization was needed to adequately represent chantways in written form. As he learned from his tutors, materials and songs and sandpaintings could be conveyed outside of the chantway, but their power was neutralized because the elements were disconnected from one another. Matthews' relationships with his tutors seems to have helped him realize that systems of knowledge structured practices that seemed similar-Navajos were certainly not the only people to place meaning in orientation, or to draw sandpaintings, or to sing in a hieratic mode-but which were constituted by different cosmologies.

Sandpaintings made during a chantway presented yet another particular problem of documentation due to their ephemeral status and potential to cause unintended harm. Sandpaintings existed for only mere hours in material form, during which time they served to draw Holy People to the ceremonial and, if properly executed, attend to the requests of the medicine singer (Matthews, 1902; Parezo, 1983). The sandpaintings were then destroyed, their healing powers exhausted and the sand compromised by the transfer of illness from the patient to the painting. Regarding ritual dispersal, Matthews based his interpretation on a notion of the protection of intellectual property disguised as "secrets" and a lack of inscriptive techniques in use among the Navajo:

\footnotetext{
${ }^{36}$ Washington Matthews, Manuscripts for Various Songs (\#674; circa 1892-1894), WMP; Washington Matthews, Navaho Song Book and Cylinder Record (circa 1894), WMP.

${ }^{37} 76$ of Matthews' cylinder recordings are held today in Indiana University's Archives of Traditional Music.
} 
The custom of destroying these pictures at the close of the ceremonies and preserving no permanent copies of them arose, no doubt, largely from a desire to preserve the secrets of the lodge from the uninitiated; but it had also perhaps a more practical reason for its existence. The Navahoes had no way of drawing permanent designs in color (Matthews, 1902, p. 36).

Matthews, however, did have such a way of "drawing permanent designs in color:" his notebooks, pencils, and watercolors. The trouble of documenting sandpaintings was that Matthews could only see them in situ, in Navajoland, during the winter months when chantways such as the Nightway and Mountainway could be performed. Representation of the complex materials and processes of sandpainting creation posed another issue. Cameras were out of the question as they would disrupt the ceremonial, not to mention irresponsibly reproduce the image of the sandpainting permanently and thus potentially imperil the patient.

Even with allied singers to vouch for him, other singers or Navajos of stature occasionally raised opposition to Matthews' sketching during a ceremonial; in these instances, the surgeon put away his work and focused intently on memorizing the designs as well as possible. Notetaking and memorization were daunting tasks, however, given the procession of multisensorial events that also occurred during sandpainting creation. Overwhelmed by the sheer number of elements that composed a chantway, Matthews was forced to choose between, for instance, memorizing the sandpainting's important color scheme versus the oral chants and prayers performed during the construction, healing, and dispersal of the sandpainting. Although time was limited during a ceremonial, Matthews also drew on his relationships with Laughing Singer, Tall Chanter, and others who consented to let him view select parts of a sandpainting, outside of its formal enactment, and he paid them for this opportunity. ${ }^{38}$

Matthews worked piecemeal on sandpaintings, and in none of his notebooks did he record a single, whole image. His early sketches from the 1884 Mountainway included watercolors in his notebook, painted from memory in the isolation of his own tent. For other sketches, Matthews noted color in the margins if he could not reproduce it, for he grasped that colors had meaningful associations in Navajo cosmology. ${ }^{39}$ In his notebooks, Matthews isolated different components of the overall image, such that gods, animals, ornaments, and other facets were illustrated on subsequent pages. To reconstruct his deconstruction, he sketched a rough diagram of the overall composition. Later, with the help of an artist, Matthews synthesized these into a representation of the sandpainting design, piecing together different singer's sandpaintings to compose a "typical" rendition of the image, one that suited the scholarly goal of identifying the important elements for Navajo practitioners, even if the complete image itself had not been presented to him by any individual singer. ${ }^{40}$

Due to the ephemeral quality of sandpaintings, the memories of medicine singers also raised questions of reproducibility. Matthews had some reservations about the proclaimed ability of Navajo singers to reproduce sandpaintings exactly as they had been taught, years ago.

No permanent design is preserved for reference, and there is no final authority in the tribe. The majority of the ceremonies can be performed only during the months when the snakes are dormant. The pictures are therefore carried over, from winter to winter, in the fallible memories of men (Matthews, 1885, p. 934).

Though troubled by the distributed nature of Navajo knowledge authority and a singer's claim that all practitioners reproduced the same set of sandpaintings for a given chantway, Matthews' two detailed studies of

\footnotetext{
${ }^{38}$ Matthews (1897b) explained the importance of paying informants. Some records of payment can be found in his papers, for example, Washington Matthews to Pliny Goddard, Letter, January 16, 1904, WMP.

${ }^{39}$ Matthews, "San Mateo and Hackan," WMP.

${ }^{40}$ The sandpainting plates present in Matthews' major works were all Anglo-illustrated reproductions of piecemeal sketches of sandpaintings made in the field-it was not until later that sandpainting photographs (i.e., images of singer-composed sandpaintings) were circulated through the photographic work of Edward Curtis.
} 
chantways indicated that sandpaintings from different practitioners (and different times) had many more similarities than differences. Prescribed sandpaintings shared the same depictions, including similar intricate details, yet each singer had an artfulness and style. In this regard, Matthews recognized that claims of exactitude meant something different to Navajo singers, that their adequation of sandpaintings was both fixed and allowed for creative elaboration. Singers understood replicability not as a technical one-to-one replication, but rather as a mnemonic reproduction, a pattern that could be passed on while subtly morphing to fit a new singer's preferences. Singers-in-training came to possess a form of "trained judgment" regarding their representations in sandpainting, whereby their expertise with the theory and practice allowed them to "smooth" paintings to fit their own styles of practice without divorcing from their effects. ${ }^{41}$ For Matthews, with some instruction but lacking the practitioner's years of experience, to document sandpaintings he had to separate the parts and recompose the images to best emulate their ideal-typical instance, whereby the pattern could be replicated but the individualized components diminished.

\section{5 | A SCIENCE OF CEREMONY?}

Through Navajo tutors, Matthews came to see chantways as an integrated practice, rooted in a place and produced (and dispersed) in time. The sandpainting's creation and eventual dispersion, in a sense, mirrored the event itself. Through the several days of events, singers, assistants, performers, and storytellers came together to share stories and reconnect with one another. Navajo visitors renewed their connection to relatives and recalled and passed on the worldview informed by their intellectual traditions. Then, when the 9-day ceremonial concluded, participants and visitors dispersed and returned to their lives in other parts of Navajoland.

As his studies continued, Matthews appreciated that Navajo ceremonialism was a coherent, organized, and even professionalized practice, against prevailing assumptions about the unsophisticated character of indigenous peoples and their esoteric practices. For Matthews, recognizing indigenous complexity made it all the more urgent that Indian belief systems be documented and preserved; as the most esoteric and often secretive elements of indigenous society, "religions" were most in danger of being lost without even being acknowledged in the first place. To promote documentation and preservation, he believed that a standardized study of ceremony would attune researchers to important components that were at risk of being lost amid Anglo-American settler colonialism (Matthews, 1897b). But could a standardized suite of documentation practices be raised to the level of a comparative science?

During a joint meeting of the American Associate for the Advancement of Science and the American Folk-Lore Society in August of 1897, Matthews presented a case for "The Study of Ceremony," which was later published in the Journal of American Folk-Lore. Having asked a "scientific friend, an anthropologist," what he might name a science of ceremony, the friend suggested he stop searching for a name, telling Matthews "you can create no science of ceremonies, and can form no laws concerning them." Matthews agreed that it appeared that ceremonial laws could not be drawn, but he suggested that an ethnographic toolkit might be composed to work toward generalizable ceremonial analysis. An "accurate" study of ceremony offered many benefits from Matthews' point of view. "I believe, as the result of an extensive experience, that ceremony offers material for the study of human development equal to that offered by art, government, legend, or any other subject of ethnologic investigation." 42

Matthews gave a list of problems that had prevented ethnographers from conducting a scientific study of ceremony and outlined the interlocking requirements for an ethnography of ceremony. To begin, he asserted,

\footnotetext{
${ }^{41}$ Daston and Galison (2007). For anthropological work addressing replication in indigenous art, see Michaels (1994).

${ }^{42}$ Matthews (1897b, p. 258). In this text, he toyed with assigning the study of ceremony a scientific nomenclature-Jesse Walter Fewkes, a researcher working nearby at the Hopi Mesas had already proposed a field to be called "ceremoniology" in 1893-but ultimately Matthews decided he could not think of a proper term to designate the proposed field.
} 
researchers must spend time in the field. "The gleaners of ethnological notes have been, heretofore, mostly of the wandering kind," wrote Matthews. The ethnologists needed to plant roots in the community, needed to acquaint themselves with the informant and gain his or her trust. Given time and acceptance, the fieldworker would find new information available to him, especially regarding ceremonial matters. "Ceremony, even of a merely worshipful character, is one of the things about which people are sensitive and reticent," Matthews acknowledged. By building relationships, the anthropologist's subjects would be more open with sacred matters. This insider status also enabled the fieldworker to comprehend the overall spiritual system better, for sacred knowledge practices could not be fully comprehended until the antecedent or more secret elements of the rite were also known (Matthews, 1897b, p. 258).

To make an "accurate" study of ceremonialism, the elements of time and trust had to be attached to an unbiased mind; it was not merely a matter of writing down information, but rather an endeavor that required an ethnographic observer who could be trusted to obtain accurate information from close-knit informants. Matthews believed that "until recently there were very few white men who could entirely divest themselves of their early bias, who could altogether rid themselves of an inbred contempt for pagan rites, or who, in the presence of pagans, conceal their antipathy to the performance of what George Catlin calls 'hocus-pocus'." Calling out the famed painter of Indian life, Matthews emphasized that unbiased (or at least feigned) interest in ceremonial practices was essential, not just for scientific credibility, but also because "the slightest evidence of disdain on the part of the inquirer easily closes the door to knowledge" (Matthews, 1897b, p. 258). Matthews here recognized that an ethnographer's comportment and mentality were just as important as thorough documentation. Just as the Navajo medicine singers knew the Holy People would respond only to correct comportment and legitimate appeals for healing, the ethnographer needed to show his open-mindedness to a ceremonial practice and its underlying theory, both to gain the assurance of his hosts and to endear himself as a respectful visitor, even while he faced morally shocking or strange customs. Navajo ceremonialists would only allow Matthews' presence if he treated them as equals-as healers and doctors for their people, just as he was for his. While the doctrine of cultural relativism that later emerged in anthropology bolstered a new ethics of cross-cultural fieldwork, Matthews' attempt to document chantways shows that the conditions of possibility for fieldwork itself demanded a relativistic perspective from the ethnographer.

Matthews accommodated the beliefs of his indigenous hosts in the field (even if he did not subscribe to them himself) and suggested that scholars hoping to view ceremonies do the same: the ethnographer may have "to feign a reverence which he does not feel; but in so doing he should remember that he performs an act of simply courtesy, and need not accuse himself of hypocrisy." He lamented that "observers are likely to underrate the character of the people with whom they are dealing" and that, instead, ethnographers had to take seriously their human subjects, to be willing to be surprised by their ingenuity and complexity. This also required patience for acts that appeared repetitive, monotonous, silly, or tedious to the inquirer, for "in omitting to note the apparently most trifling particulars, he may lose the most valuable material for comparative study" (Matthews, 1897b, p. 259) Here, Matthews linked patient, respectful, and immersive in situ observation to scientific credibility.

Finally, Matthews provided a practical tip for ethnographic inquiry: pay informants fairly for information they held dear. Informants with high social status, such as Tall Chanter and Laughing Singer, understood the value of their knowledge. The ceremonial specialist, it followed, "is not willing to surrender all he knows to a stranger for a trifle. If he thinks he will receive but a cup of coffee and a plug of tobacco for his pains, he is likely to impart information to that value and no more" (Matthews, 1897b, p. 259). At times the knowledge may be too great or too precious to convey to an outsider. All manner of knowledge specialists, Matthews asserted, made judgments about who can and cannot access knowledge to protect its credibility, and Indians were no different from whites in this regard.

If ceremony researchers carefully practiced these traits-traits that Matthews himself had embodied in his fieldwork practice-they might penetrate "rites of an esoteric character," which for Matthews meant rites dictated by an internal, and often publicly obscured, rationale. Access to sacred events was an earned privilege. One could 
not expect to waltz into an Indian settlement and simply ask the priest about the most intimate and sacred parts of spiritualism. Ethnographers had to demonstrate their ability to respectfully deal with indigenous knowledge by signaling comprehension of the importance of ceremonialism, conveying to their informants that indigenous knowledge would be held at special and important level, akin to Anglo scientific knowledge. To show their recognition of the value indigenous knowledge, ethnographers had to offer goods or services equivalent to the extensive labor of sacred knowledge maintenance and continuation.

In Matthews' interactions with Tall Chanter and Laughing Singer, he surely demonstrated to them his appreciation of their knowledge practices. Still, the extent to which Matthews feigned his appreciation is difficult to determine. He clearly respected Tall Chanter and Laughing Singer and considered them dear friends. But he forged these relationships, in the end, with a goal of information extraction. To forge strong friendships and obtain access to ceremonial data required he adopt an open-minded perspective while in the field and convey that perspective to his hosts. Regardless of whether his performed veneration was authentic or a feigned "courtesy" to Tall Chanter and Laughing Singer (or a mixture of both), Matthews nonetheless communicated the usefulness of cultural relativism for data extraction to the nascent discipline of anthropology. Matthews passed on to his disciplinary brethren the lesson taught to him by Tall Chanter and Laughing Singer: that indigenous knowledge and its keepers required respect and reverence.

Matthews' proposed refinement of the study of ceremony was liberal in its treatment of Native practices, but parochial in who was deemed an authoritative researcher, who could produce legitimate scientific data for comparison. Even though he had received formal training under Laughing Singer and Tall Chanter and had strong relationships with knowledgeable Diné informants such as Ben Damon, Chee Dodge, and Jake the Silversmith, Matthews ultimately believed an outsider-himself-the proper figure for gathering information about Navajo ceremonialism. In print, Matthews took an equivocal position on the ability of Navajos to explain their "religion" to outsiders. "There is little to be gained by asking a Navaho direct questions about this. Learned controversialists and theologians, capable of analyzing and discussing their faith, have not arisen among them, or, if they have, they cannot easily communicate their philosophy to us" (Matthews, 1897a, p. 33). Informants gave information, not thoroughgoing analysis; the ethnographer served as a cypher or medium through which indigenous "religion" could be made legible for Anglos (Matthews, 1897a, p. 33). To Matthews, in his position as an unbiased outsider looking in, only the ethnographer was able to capture data and shape analysis within the frame of social science.

The "civilized" scholar was, to Matthews, the only one equipped to apply comparative analysis of ceremonials across indigenous groups. Drawing on social evolutionary theory, he situated indigenous religion on a scale of intellectual advancement, in which he saw secularized European and American practices as containing previous religious (even superstitious) beliefs out of which current practices had evolved. He insisted that "some of the most interested survivals in the history of human development are to be found in the rites of secret societies," meaning the seeds of religious practices were inborn to all human communities. Religious practices evolved, but "a comparative study of worship will show that the same principles control the forms of worship among the lowest and the highest" (Matthews 1897b, p. 259). Comparative study, he hoped, would reveal the historical evolution of ceremonialism into its secular, social forms present in "civilized" nations at the turn of the twentieth century. Thus, Matthews asserted there was a wide field for ceremonial study, "not only among the barbarous races of the old world, and rustic Europeans, but among the most enlightened and exalted members of our own race. Among the latter we trace, with astonishing clearness, the survival of savage customs" (Matthews, 1897b, p. 259). Study of ceremonial or esoteric practices, then, proposed to provide insight into human sociality, from the "savage" to the "enlightened."

Charting such a model of development, Matthews appeared to accept the moral weight of the reigning late-nineteenth-century theory of social evolutionism and its linear scale of societal advancement from savagery to civilization. But, instead of emphasizing cultural superiority, Matthews stressed that the judgment of a social group within a hierarchical scheme should not alter the analysis of its contents. He knew from his relationships with Navajo knowledge-keepers that indigenous peoples possessed sophisticated systems of reasoning, which became 
legible only if the scientist (as he had) kept an open mind. These ideals, progressive for their time, had been forged by Matthews' experiences with Navajo singers and his struggle to produce a scientific monograph about their "religion" and its myriad facets. He had accumulated notebooks full of data, from a range of ephemeral events that touched on all of his senses. The comparative study of ceremony would only be legitimate once ethnographers inscribed information from diverse indigenous groups in a thoroughgoing manner. Ethnographers, following his model and innovating based on their own experiences in the field, should turn away from tabular lists, turn away from judgmental dismissal of esoteric and strange rites, and focus on internal systems of meaning-making and transmission. Only by drawing unique, exhaustive studies together could anthropologists compose a "science" of ceremony. But first, ethnographers had relationships to foster and experiences in the field to be gained.

\section{6 | PUBLISHING A TOTAL EVENT: MATTHEWS' THE NIGHT CHANT (1902)}

Though ultimately ambivalent about a "science" of ceremony, Matthews continued to apply himself to detailed study of Navajo ceremonialism following "The Study of Ceremony." Building on the methods he had developed in "The Mountain Chant" and Navaho Legends, in 1902 Matthews published a 300-page monographic study of the Navajo Nightway. The work, entitled The Night Chant: A Navaho Ceremony, began with "general observations and elements of the ceremony," what amounted to a list of things that set the stage for and helped execute the chantway. Matthews began by discussing Navajo ceremonies and medicine singers in general, and then moved to the Nightway ceremonial in particular. He offered short explanations of discrete elements that composed the Nightway, which included its seasonal limitations, the symbolism presented, the gods referenced, the sandpaintings and ceremonial offerings, the herbs and medicines, the ceremonial spaces and medicine lodge, and the masks and dances. Overall, the first section gave an indication of the overall constellation of affects that Navajo singers drew together during the ceremonial.

The second section, "rites in detail," featured the sequence of the Nightway. It was cast chronologically, from the first day to the ninth night, and ran almost 100 pages. Each paragraph was numbered, as it was throughout the text, and although it followed a basic narrative-a "disinterested" Matthews witnessing the Nightway events in time-the format was heavily structured with subheadings and excursuses. He also included songs, translated into English verse, and illustrations of ceremonial paraphernalia, indented against the main text. Because the ceremonial was so lengthy, the numbered paragraphs allowed Matthews to refer to elements that had been, or were to be, mentioned.

"Myths" composed the third section of the book, and began with the story of "The Visionary," the original heroic recipient of the Nightway from the Holy People. Several variants of this myth and related stories were also presented. The fourth and final part of the monograph was composed of "texts and translations" of the songs and prayers given during the course of events. He presented the selected songs in interlinear Navajo and English translation, and included remarks on each song, frequently referencing his "free translations" in the main text of the ceremonial's procession. When, for instance, the sequential narrative of the rites presented a song (section two), the reader could thumb to this later section for a fuller version of the hymnody. Songs and prayers came last in the text in part because, as Matthews explained, "they often allude to matters which the hearers are supposed to understand. They are not like our ballads-they tell no tales. He who would comprehend them, must know the myths and the ritual customs on which they are based" (Matthews, 1902, p. 270). Matthews reported the presence of over 400 songs in the Nightway, noting that some diverged from one another by only several words and thus he had selected only representative songs.

Eight full-color plates of sandpaintings and ceremonial paraphernalia were included in the volume. Three of these plates were by a Washington painter, Delancy W. Gill, who painted the sandpaintings after drawings and descriptions by Matthews. These Matthews apparently showed to several singers "for observation and comment, to 
meet with invariable approval" (Matthews 1902, 316n77). Although he recorded no objection to his permanent images, singers outside of Matthews' immediate circle presumably may have objected to these illustrations.

The Night Chant diverged widely from the format of "The Mountain Chant," published nearly 15 years prior. The earlier work, only 80-some pages in length, had come from only several months of ceremonial study. The Night Chant, by contrast, was informed by over a decade of intensive study, developed through strong relationships with his Navajo tutors. His training from singers made him appreciate the depth of knowledge and history that permeated chantways and gave them healing powers. Matthews had also come to realize that ceremonialism was ultimately an ineffable event:

I have witnessed the ceremonies of the [Nightway] in whole or in part a dozen times or more and every time I have observed something new. And yet there are some parts I have not observed, but depend for my knowledge of them on information obtained from the shamans. Half a dozen skilled observers each watching a different part of the work could not note all that pertains to the ceremony on one occasion, nor could they, without long study of the work have a suspicion of what they might have missed (quoted in Faris, 1990, p. 49).

Training with a medicine singer, for one, allowed the ethnographer to understand the complexity of the multi-day chantway. But also, as trainers and trainees well knew, a single ceremonial could not enlighten the spectator to all of its intricacies. Instead, its secrets had to be unlocked through diligent scholarship, practice, and the maintenance of ties with other singers. ${ }^{43}$

There was no short-cut to a scientific ethnography of ceremonials, to Matthews' mind. To document a long, complex, multisensorial event-a chantway, perhaps-required dedication, interpersonal cultivation, and a mind open to the myriad differences in knowledge systems scattered about the world. But the dilemma of documentation did not mean that a science of ceremony might not one day emerge. Though intimately tied to his Navajo informants-bound by friendship and tutelage-Matthews maintained allegiance with the scientific maxim of the collection and free circulation of worldly phenomena. Matthews' own quest to capture the complexities of ceremonialism indicated that field workers in the human sciences in the late nineteenth century could study (and publish on) ephemeral, multisensory cultural practices. The data produced could be used for comparison-and if given enough adequate material, perhaps be raised to the level of a science -but Matthews also showed that the ethnographic monograph could also become a holistic body of evidence in itself, something to be filed away as an appreciative illustration of indigenous practices featuring sensorial complexity and a host of ineffable effects.

And that, perhaps, was enough. Matthews hewed to the aspirations of late-nineteenth-century ethnology to construct universal laws but learned the advantage of relativism in the process. Tall Chanter, Laughing Singer, and other Navajo chantway practitioners showed Matthews the contextual nature of truths-even if he did not fully recognize this exchange. His tutors seemed to know that Matthews' documents were not the Nightway, not the Mountainway. They amounted to something else entirely: a select rendering of ceremonial practices conveyed to him, a strategy of documentation and redimensionalization for Anglo audiences, and an experiment in the organization of multisensorial and ephemeral ethnographic material as an object of scientific information.

\section{ACKNOWLEDGMENTS}

The author would like to humbly acknowledge the continued support of the School for Advanced Research (Santa Fe), the Wheelwright Museum Archives, the Science, Technology and Society Program at the University of Michigan (and its manuscript workshop), and the American Philosophical Society. Special thanks go to Howard

\footnotetext{
${ }^{43}$ For the "ineffable" as a problem in later social science, see Stark and Campbell (2018).
} 
Brick, John Carson, Henry Cowles, Philip Deloria, James Faris, Kathryn Holihan, Liz Roberts, Joy Rohde, Daniel Williford, and the editors and reviewers at JHBS.

\section{REFERENCES}

Bendix, R. (2009). In search of authenticity: The formation of Folklore studies. Madison: University of Wisconsin Press.

Bieder, R. E. (1986). Science encounters the Indian, 1820-1880: The early years of American Ethnology. Norman: University of Oklahoma Press.

Cohen-Cole, J. (2014). The open mind: Cold War politics and the sciences of human nature. Chicago: University of Chicago Press.

Cushing, F. H. (1883). Zuñi Fetiches. Second annual report of the Bureau of Ethnology, 1880-1881, 3-45.

Cushing, F. H. (1886). A study of Pueblo Pottery as illustrative of Zuni culture growth. Washington: US Government Printing Office.

Darnell, R. (1998). And along came Boas: Continuity and revolution in Americanist anthropology. Amsterdam, the Netherlands: John Benjamins Publishing.

Darnell, R. (2001). Invisible genealogies: A history of Americanist anthropology. Lincoln: University of Nebraska Press.

Daston, L., \& Galison, P. (2007). Objectivity. New York: Zone Books.

Farella, J. R. (1990). The main stalk: A synthesis of Navajo philosophy. Tucson: University of Arizona Press.

Faris, J. C. (1990). The Nightway: A history and a history of documentation of a Navajo ceremonial. Albuquerque: University of New Mexico Press.

Faris, J. C. (1997). Some observations on the ethical integrity of Washington Matthews in Navajo research. In K. S. Halpern \& S. B. McGreevy (Eds.), Washington Matthews: Studies in Navajo culture, 1880-1894 (pp. 79-88). Albuquerque: University of New Mexico Press.

Fowler, D. D. (1975). Notes on inquiries in anthropology: A bibliographic essay. In T. H. H. Thoreson (Ed.), Toward a Science of Man. Essays in the history of anthropology. Mouton Press.

Frisbie, C. J. (1997). Washington Matthews' contributions to the study of Navajo ceremonialism and mythology. In K. S. Halpern \& S. B. McGreevy (Eds.), Washington Matthews: Studies in Navajo culture, 1880-1894 (pp. 28-41). Albuquerque: University of New Mexico Press.

Green, J. (Ed.), 1979). Zuñi. Selected writings of Frank Hamilton Cushing. Lincoln: University of Nebraska Press.

Green, J. (Ed.), 1990). Cushing at Zuni: The correspondence and journals of Frank Hamilton Cushing, 1879-1884. Albuquerque: University of New Mexico Press.

Haile, B. (1938). Navaho chantways and ceremonials. American Anthropologist, 40(4), 639-652.

Haile, B. (1938). Origin legend of the Navaho Enemy Way: Text and translation. New Haven: Yale University Press.

Halpern, K. S., \& McGreevy, S. B. (Eds.), 1997). Washington Matthews: Studies of Navajo culture, 1880-1894. Albuquerque: University of New Mexico Press.

[Halpern] Spencer, K. (1957). Mythology and values: An analysis of Navaho chantway myths. University of Texas Press.

Halpern, K. S. (1997). Washington Matthews' Folklore studies. In Halpern, K. S., \& McGreevy, S. B. (Eds.), Washington Matthews: Studies in Navajo culture, 1880-1894 (pp. 89-102). Albuquerque: University of New Mexico Press.

Hinsley, C. M. (1981). The Smithsonian and the American Indian: Making moral anthropology in Victorian America (1994). Washington, DC: Smithsonian Institution Press.

Hinsley, C. M. (1999). Life on the margins: The ethnographic poetics of Frank Hamilton Cushing. Journal of the Southwest, 371-382.

Hinsley, C. M. (1983). Ethnographic charisma and scientific routine: Cushing and Fewkes in the American Southwest, 1879-1893. In Stocking, G. W. (Ed.), Observers observed: Essays on ethnographic fieldwork. Madison: University of Wisconsin Press.

Johnson, A. F. (2018). Secretsharers: Intersecting systems of knowledge and the politics of documentation in southwesternist anthropology, 1880-1930 (PhD dissertation). University of Michigan.

Kluckhohn, C. (1944). Navaho Witchcraft. Papers of the Peabody Museum, Harvard University, 22(2), 33-72.

Kluckhohn, C. (1949). The philosophy of the Navaho Indians. Ideological Differences and World Order, 356-384.

Lemov, R. (2015). Database of dreams: The lost quest to catalog humanity. New Haven: Yale University Press.

Letterman, J. (1856). Sketch of the Navajo tribe of Indians, territory of New Mexico. Washington: Smithsonian Institution.

Mark, J. (1980). Four anthropologists: An American science in its early years. New York: Science History Publication.

Matthews, W. (1877). Ethnography and philology of the Hidatsa Indians. Washington: US Government Printing Office.

Matthews, W. (1883). Navajo silversmiths. Second annual report of the Bureau of Ethnology, 1880-1881, 167-178.

Matthews, W. (1884). Navajo weavers. Third annual report of the Bureau of Ethnology, 1881-1882, 371-391.

Matthews, W. (1885). Mythic dry-paintings of the Navajo. American Naturalist, 19(10), 931-939. 
Matthews, W. (1887). The Mountain Chant: A Navajo ceremony. Fifth annual report of the Bureau of Ethnology, 1883-1884, 379-467.

Matthews, W. (1892). A study in butts and tips. American Anthropologist, 345-350.

Matthews, W. (1894). The basket drum. American Anthropologist, 7(2), 202-208.

Matthews, W. (1896). Songs of the Navajos. Land of Sunshine, 5, 197-201.

Matthews, W. (1897a). Navaho legends. American Folk-Lore Society, 5, 1-299.

Matthews, W. (1897b). The study of ceremony. Journal of American Folk-Lore, 10(XXXIX), 257-263.

Matthews, W. (1898). Some sacred objects of the Navajo rites. Archives of the International Folklore Association, 1, $227-247$.

Matthews, W. (1901). A Navajo initiation. Land of Sunshine, 15, 353-356.

Matthews, W. (1902). The Night Chant: A Navaho ceremony. New York: Knickerbocker Press.

Michaels, E. (1994). Bad aboriginal art and other essays: Tradition, media, and technological horizons. Minneapolis: University of Minnesota Press.

Parezo, N. J. (1983). Navajo sandpainting: From religious act to commercial art. Tucson: University of Arizona Press.

Parezo, N. J. (1985). Cushing as part of the team: The collecting activities of the Smithsonian Institution. American Ethnologist, 12(4), 763-774.

Parezo, N. J. (2006). Collecting dine culture in the 1880s: Two army physicians and their ethnographic approaches. Museum Anthropology, 29(2), 95-117.

Parezo, N. J. (1997). Matthews and the discovery of Navajo drypaintings. In K. S. Halpern \& S. B. McGreevy (Eds.), Washington Matthews: Studies in Navajo culture, 1880-1894 (pp. 53-78). Albuquerque: University of New Mexico Press.

Poor, R. M. P. (1975). Washington Matthews: An intellectual biography (Master's thesis). University of Nevada.

Reichard, G. A. (1950). Navaho religion. New York: Pantheon Books.

Rheinberger, H.-J. Ö. (2010). An epistemology of the concrete: Twentieth-century histories of life. Durham: Duke University Press.

Schwarz, M. T. (2003). Blood and voice: Navajo women ceremonial practitioners. Tucson: University of Arizona Press.

Shapin, S. (2012). The sciences of subjectivity. Social Studies of Science, 42(2), 170-184.

Simpson, J. H., \& McNitt, F. (1964). Navaho expedition: Journal of a Military Reconnaissance from Santa Fe, New Mexico, to the Navaho Country Made in 1849. Norman: University of Oklahoma Press.

Stark, L., \& Campbell, N. D. (2018). The ineffable: A framework for the study of methods through the case of mid-century mind-brain sciences. Social Studies of Science, 48(6), 789-820.

Turner, H. E. (2015). Information infrastructures in the museum: Documenting, digitizing, and practising ethnographic objects in the Smithsonian's Department of Anthropology (PhD dissertation). University of Toronto.

Webster, A. K. (2004). Coyote poems: Navajo poetry, intertextuality, and language choice. American Indian Culture and Research Journal, 28(4), 69-91.

Webster, A. K. (2009). The poetics and politics of Navajo ideophony in contemporary Navajo poetry. Language \& Communication, 29(2), 133-151.

Wilner, I. (2013). A global potlatch: Identifying the indigenous influence on western thought. American Indian Culture and Research Journal, 37(2), 87-114.

Wilner, I. (2016). Raven cried for me: Narratives of transformation on the northwest coast of America (PhD dissertation). Yale University.

Witherspoon, G. (1977). Language and art in the Navajo universe. Ann Arbor: University of Michigan Press.

Wyman, L. C. (1970). Sandpaintings of the Navaho shootingway and the Walcott collection. Washington: Smithsonian Institution Press.

Wyman, L. C. (1975). The Mountainway of the Navajo. University of Arizona Press.

Wyman, L. C., \& Kluckhohn, C. (1938). Navaho classification of their song ceremonials. American Anthropological Association. Zolbrod, P. G. (1981). From performance to print: Preface to a native American text. The Georgia Review, 35(3), 465-509.

Zolbrod, P. G. (1998). On the multicultural frontier with Washington Matthews. Journal of the Southwest, 40(1), 67-86.

Zolbrod, P. G. (1997). Washington Matthews writes a ballad: The anthropologist as poet and literary scholar. In K. S. Halpern \& S. B. McGreevy (Eds.), Washington Matthews: Studies in Navajo culture, 1880-1894 (pp. 103-124). Albuquerque: University of New Mexico Press.

Zumwalt, R. L. (1988). American Folklore scholarship: A dialogue of dissent. Bloomington: Indiana University Press.

\section{Archival Collections}

Washington Matthews Papers (WMP), Wheelwright Museum Archive, Santa Fe, New Mexico. 


\section{AUTHOR BIOGRAPHY}

Adam Fulton Johnson is a visiting researcher at the University of Michigan, where he also received his PhD (History) in 2018. His work looks at histories of human science research in indigenous communities, centered around questions of the aims of data accumulation and the limits of publicly available information. He is currently preparing a book manuscript on the "politics of documentation" arising in cross-cultural relationships between anthropologists and indigenous communities in the Southwestern United States. Correspondence can be directed to adamfjohnson@gmail.com.

How to cite this article: Johnson AF. Documenting the multisensory and ephemeral: Navajo Chantway singers and the troubles of a "science" of ceremonialism. J Hist Behav Sci. 2019;55:230-251. https://doi.org/10.1002/jhbs.21980 